\title{
Washington Monthly
}

(https://washingtonmonthly.com).

\section{Yes, Donald Trump Can Obstruct Justice}

As Mueller's probe intensifies, Trump supporters think it's a legal impossibility. But that's not what the Constitution's framers had in mind.

by Peter Shane_(https://washingtonmonthly_com/people/peter-shane/).

December 15, 2017

POLITICS (https://washingtonmonthly.com/politics/).

$\mathrm{D}$ onald Trump may be in legal trouble whether or not Special Counsel Robert Mueller finds evidence that he had anything to do with Russian interference in the 2016 election. That's because, by asking FBI Director James Comey to drop the investigation of Trump's recently dismissed national security adviser, Michael Flynn, and firing Comey weeks later, Trump exposed himself to possible charges of obstruction of justice.

Sensing the danger, Trump supporters have tried to get out in front of the obstruction charge by claiming that it's a legal impossibility. One of the president's private attorneys recently argued that the "President cannot obstruct justice because he is the chief law enforcement officer under [the Constitution's Article II] and has every right to express his view of any case."

Academic sympathizers like Professors Alan Dershowitz and Andy Grewal have made the same point with more precision, but also more categorically. They insist that presidents cannot be charged with obstruction of justice for exercising any of their constitutional powers. As Grewal puts it, Trump might have a defense to a criminal prosecution for obstruction because his supervision of a Justice Department investigation amounts to an "official act," and "an attempt to criminalize the President for one of his official acts" could "improperly diminish the powers assigned to him by the Constitution."

An "official acts" defense is nonsensical, however-unless we want to give up the rule of law. To act "corruptly," which is a key element of the federal obstruction statute, is to act with an impermissible purpose. Proof of obstruction does not require that the act-firing someone, giving an order-be unlawful 
on its own, but rather that the reason it was done be dishonest or improper. Nothing in the Constitution authorizes a president to act corruptly.

Bribery provides the perfect example. Former Virginia governor Bob McDonnell was convicted of fraud and extortion after accepting lavish gifts from a Virginia businessman, Jonnie Williams. In exchange, McDonnell had helped Mr. Williams by setting up meetings, hosting events at the governor's mansion, and facilitating contacts with other officials that could prove beneficial to Mr. Williams's business.

Last year, the Supreme Court overturned the conviction. In McDonnell v. United States, it ruled that the theory underlying the charges of both fraud and extortion was really one of bribery. Hence, definitions delimiting the elements of federal anti-bribery law would have to apply also in defining what would count as fraud and extortion in McDonnell's case. Under the anti-bribery statute, the only ground on which the prosecution could be pursued was an "official act." McDonnell couldn't be convicted, the Court ruled, because the favors he provided Williams didn't involve him using his legal powers as governor, and thus didn't qualify as official acts.

Now imagine a president who has agreed to take money in exchange for pardoning a particular miscreant, or vetoing a particular bill, or nominating an industry lobbyist to a Cabinet post. The acts thus promised-a pardon, a veto, and a nomination-would be textbook examples of official acts over which the president is often said to have complete discretion. Following McDonnell, if "official acts" like these cannot be the basis for criminal prosecutions of the president, then the president, under law, could never be guilty of accepting a bribe. The "official acts" defense would turn the law on its head. It would certainly come as a shock to the Constitution's framers, who made bribery, along with treason, an explicit ground for impeachment.

Bribery and obstruction of justice are similar precisely because, in both instances, ordinarily lawful behavior becomes unlawful because of the reason it was done. Unless linked to an official act, a bribe is merely a gift. Unless linked to a corrupt purpose, an official act is just an exercise of lawful discretion. Shutting down an investigation to help oneself or one's allies would plainly be corrupt. Barring such selfserving presidential acts no more limits a president's constitutional powers than a ban on taking bribes. The only difference is evidentiary; the existence of a third-party "briber" makes corruption easier to 
prove than self-dealing. But if a corrupt inducement to an official act can be shown, it cannot sensibly make a constitutional difference that the inducement starts in the calculating mind of the president, not with a corrupt confederate.

Professor Grewal points to a decision of the Supreme Court of Texas which, on separation of powers grounds, dismissed the state prosecution of former Governor Rick Perry for his allegedly abusive use of the executive veto power. Specifically, it was alleged that Perry threatened to veto (and did veto) an appropriation to the Public Integrity Unit of the Travis County District Attorney's Office unless Travis County District Attorney Rosemary Lehmberg resigned. A majority held that "[n]o law passed by the [Texas] Legislature can constitutionally make the mere act of vetoing legislation a crime," regardless of the Governor's motivation.

It is important to note, however, that the explicit premise of the majority opinion was that the Texas Constitution differs from the federal Constitution in its treatment of the separation of powers:

Unlike the United States Constitution, the Texas Constitution contains an express Separation of Powers provision ... Our cases have given weight to this distinction: "All other things being equal, this textual difference between the United States and Texas constitutions suggests that Texas would more aggressively enforce separation of powers between its governmental branches than would the federal government.

I personally think the decision was still incorrect, but, regardless, the starting point for the Texas Supreme Court was that Texas separation of powers law differs from federal separation of powers law.

It is not yet clear whether there yet exists sufficient evidence to persuade a jury, beyond a reasonable doubt, that Donald Trump obstructed justice by asking Comey to go easy on Flynn or by firing Comey. And there is a separate issue whether presidents may be indicted and tried while in office. (The Justice Department's Office of Legal Counsel has said no, but conservative legal scholar Ronald Rotunda has said yes.) But if a federal prosecutor determines there is sufficient evidence to proceed, there is no doubt an indictment against the president at a proper point in time would be constitutional. Indeed, a core premise of the Constitution is that no one is above the law-not even the president.

Peter Shane_(https://washingtonmonthly.com/people/peter-shane/). 
Peter Shane teaches constitutional law at the Ohio State University's Moritz College of Law and is the author of

Madison's Nightmare: How Executive Power Threatens American Democracy_hthtp://www.amazon.com/madisonsnightmare-executive-threatens-democracy/dp/0226749398).

(University of Chicago Press 2009).

(c) 2018 Washington Monthly. 